\title{
Pola Kemitraan Antara Perum Perhutani Dengan Masyarakat Desa Hutan (Studi Kasus Program PKPH di Desa Kucur Dau, Kabupaten Malang)
}

\author{
Partnership Pattern between Perum Perhutani and Forest Countryside \\ Society \\ (Case Study of PKPH Program in Kucur Village, Dau District, Malang \\ Regency)
}

\author{
Eko Edi Prastyo ${ }^{1 *}$, Kliwon Hidayat ${ }^{2}$ \\ Jurusan Sosial Ekonomi Pertanian, Fakultas Pertanian, Universitas Brawijaya Malang Jln. Veteran, \\ Malang, 65145 Indonesia
}

Diterima: 29 Agustus 2016; Direvisi: 20 Oktober 2016; Disetujui: 25 November 2016

\begin{abstract}
ABSTRAK
Penyesuaian program PHBM menjadi (Pola Kemitraan Pengelolaan Hutan) PKPH yang dilaksanakan di Desa Kucur dengan 2 jenis kegiatan yaitu kemitraan penggarap lahan "Tetelan" dengan kemitraan penyadap getah pinus. Tujuan penelitian ini adalah 1) mendeskripsikan dan menganalisis pola kemitraan dan aksesibilitas petani desa hutan dalam kemitraan bagi hasil pada program PKPH di Desa Kucur Kecamatan Dau Kabupaten Malang, 2) menganalisis tingkat kesesuaian penerapan program PKPH berdasarkan kelestarian hutan oleh petani masyarakat desa hutan di Desa Kucur, 3) menganalisis perbedaan tingkat pendapatan dari sistem kemitraan Penggarap lahan "Tetelan" dengan sistem kemitraan Penyadap Getah Pinus dalam program PKPH di Desa Kucur. Sampel dalam penelitian ini sebanyak 30 petani dan beberapa Informan. Teknik analisis data yang digunakan adalah analisis deskriptif, analisis pendapatan usahatani. Hasil penelitian ini menunjukan program PKPH dijalankan oleh Perum Perhutani dan masyarakat desa hutan Desa Kucur dengan berlandaskan kesepakatan perjanjian yang isinya menjelaskan pengelolaan hutan yang lestari dan meningkatkan kesejahteraan masyarakat. Sedangakan aksesibilitas untuk masyarakat desa hutan yang ingin ikut PKPH dijalankan secara adil dan terbuka. Tingkat kesesuaian implementasi program PKPH di Desa Kucur berdasarkan kelestarian hutan pada kemitraan penggarap lahan "Tetelan" adalah berada pada kategori sedang, sedangkan pada kegiatan penyadapan pinus berada pada kategori baik. Tingkat pendapatan kegiatan penggarap lahan "Tetelan" per bulan adalah sebesar Rp442.540, pendapatan ini lebih besar daripada tingkat pendapatan kegiatan penyadap getah pinus per bulan sebesar Rp245.500.
\end{abstract}

Kata kunci: pola kemitraan; aksesibilatas; PKPH; tingkat pendapatan petani

\begin{abstract}
Adjustment PHBM program to PKPH (Partnership Pattern of Forest Management Program) conducted in Kucur Village with two types of main activities which were partnership tenant of "Tetelan" land and partnerships of tappers pine sap. The purposes of this research are 1) describe and analyse partnership pattern and accessibility farmers of forest village in partnership for outcomes PKPH program in Kucur Village, Dau District, Malang Regency, 2) analyse suitability level of PKPH application based on forest sustainability by farmers of village community forest of PKPH in Kucur Village 3 ) analyse the difference between income share of partnership pattern of "Tetelan" land and tappers pine sap of PKPH in Kucur Village. Sample of this research are 30 farmers and several informants. Data analysis technique used are descriptive analysis and income farming analysis. The result of this research showed that PKPH run by Perum Perhutani with forest countryside society in Kucur Village based on an agreement, which explain forest management sustainable and increase public welfare. Accessibility for the forest countryside society that want to join the PKPH undertaken in a fair and open. The category of suitability level of PKPH implementation in Kucur Village based on forest sustainability in partnership tenant of "Tetelan"land is medium, while the category of tapping pine activity is good. Level of income share activities in "Tetelan"land per month is IDR442,540, the income is larger than the level of income activities of tappers pine sap per month of Rp245.500.
\end{abstract}

Keywords: partnership pattern; accessibility; $\mathrm{PKPH}$; income level of farmer

http://www.habitat.ub.ac.id, ISSN: 0853-5167 (p); 2338-2007 (e) 


\section{Pendahuluan}

Hutan adalah salah satu sumber daya alam yang memiliki peran penting bagi kehidupan manusia baik dari aspek ekonomi, ekologi maupun sosial. Menurut Achirrudin (2011) Indonesia memiliki 120,35 juta hektar sumber daya hutan yang kaya akan ragam spesies dan ragam tipe ekosistem (mega biodeversity). Dari aspek sosial, hutan di Indonesia juga merupakan rumah serta tempat untuk bersosialisasi antar masyarakat. Menurut data Departemen Kehutanan 2006 dalam Ansori 2009, 48.8 juta jiwa atau $12 \%$ dari total penduduk Indonesia tinggal di dalam dan sekitar kawasan hutan. Meski demikian berdasarkan data Center for Economic and Social Studies (CESS) 2005 dalam Aji dkk, 2011 mengungkapkan bahwa sekitar $50 \%$ dari total 32 juta jiwa penduduk miskin Indonesia tinggal di kawasan hutan. Menurut Riyanto (2004) kemiskinan ini terjadi salah satunya karena masyarakat sekitar hutan hanya mendapatkan manfaat minimal dalam kegiatan pengelolaan eksploitasi sumberdaya hayati hutan yang kaya oleh pihak swasta maupun badan negara di daerahnya.

Berdasarkan UU No. 5 Tahun 1967 salah satu jenis hutan yang ada adalah hutan produksi, yang diperuntukan untuk memproduksi hasil hutan. Perum Perhutani adalah perusahaan Badan Usaha Milik Negara (BUMN) yang diberikan kewenangan oleh negara untuk melakukan pengelolaan hutan produksi di Indonesia sejak tahun 1972. Penguasaan lahan Perum Perhutani adalah sebesar 2.446.907,27 ha tersebar di Pulau Jawa dan Madura. Sebagai koreksi, pengelolaan Perum Perhutani masa lalu cenderung timber oriented, yang mana kurang memperhitungkan variabel sosial ekonomi dan budaya. Ini kemudian memunculkan disparsitas atau ketidakseimbangan dalam pemanfaatan sumber daya hutan dan meningkatnya konflik pengelolaan dengan masyarakat sekitar hutan. Hingga lahirlah paradigma baru pengelolaan sumberdaya hutan yang berbasis pada pemberdayaan masyarakat melalui kesadaran berbagi hasil, berbagi peran dan berbagi tanggung jawab.

Wujud dari hasil paradigma baru diatas ialah diluncurkanya Program Pengelolaan Hutan Bersama Masyarakat (PHBM) oleh Perum

\footnotetext{
${ }^{*}$ Penulis Korespondensi.

E-mail: ekoedip@gmail.com
}

Perhutani pada tahun 2001. Pada program PHBM ini Perum Perhutani memasukan Indek Pembangunan Manusia (IPM) sebagai bagian dari sasaran aktivitasnya. Sasaran ini dilakukan dengan ikut menyertakan Masyarakat Desa Hutan (MDH) dalam pengelolaan hutan. Tujuanya agar terjadi perubahan mindset masyarakat desa hutan untuk lebih memahami perlunya menjaga kelestarian sumber daya hutan. Selain itu diharapkan PHBM juga bisa memberikan efek yang positif lain bagi Perum Perhutani dan masyarakat desa hutan seperti adanya penyerapan tenaga kerja untuk penanaman dan pemeliharaan pohon hutan kembali, meningkatnya pengetahuan dan ketrampilan sumber daya manusia serta terjalinya hubungan yang sinergis antara Perum Perhutani dan masyarakat desa hutan.

Ada Kebijakan PHBM yang telah ditetapkan oleh Perum Perhutani umumnya berlangsung sejak tahun 2001 yaitu setelah keluarnya surat keputusan direksi Perum Perhutani. Namun program ini tidak dapat dilaksanakan di Kabupaten Malang secara langsung. Menurut Kusdamayanti (2008) terjadi konflik kebijakan antara Pemerintah Daerah (Pemda) dengan Perum Perhutani. Pemda meminta Perum Perhutani agar program PHBM lebih disesuaikan dan dilakukanya beberapa perubahan. Setelah beberapa tahun, konflik tersebut pun dapat diselesaikan melalui adanya perundingan. Pada tahun 2004 setelah terjadi perdebatan panjang disepaktilah pelaksanaan Pola Kemitraan Pengelolaan Hutan (PKPH) sebagai bentuk baru dari program PHBM di Kabupaten Malang.

Desa Kucur adalah salah satu desa hutan yang berada di Kecamatan Dau Kabupaten Malang. Desa yang berbatasan dengan lahan hutan pinus milik Perum Perhutani ini tercatat ikut dalam program PKPH di Kabupaten Malang. Pelaksanaan program ini dilakukan dengan sistem kemitraan bagi hasil antara Perum Perhutani dengan petani hutan. Terdapat dua jenis kegiatan kemitraan yaitu kemitraan penggarap lahan "Tetelan" atau lahan hutan dan kemitraan penyadap getah pinus milik Perum Perhutani. Jumlah masyarakat desa hutan yang menjadi peserta program PKPH cukup banyak yaitu sekitar 170 orang. Masing-masing kegiatan kemitraan ini memiliki aturan yang berbeda dan perlu dilakukan dilihat pelaksanaan apakah telah mengacu pada tujuan program atau tidak. 


\section{Metode Penelitian}

\subsection{Lokasi Penelitian}

Penelitian dilaksanakan di Desa Kucur, Kecamatan Dau, Kabupaten Malang, Jawa Timur. Pemilihan lokasi ini didasarkan atas pertimbangan bahwa Desa Kucur merupakan daerah Desa Hutan yang berkarakter pertanian dan sebagian dari masyarakat mengikuti kemitraan bagi dengan Perum Perhutani dalam program PKPH.

\subsection{Penentuan Sampel}

Sampel ditentukan dengan Purposive Sampling. Metode penentuan sumber data secara sengaja dilakukan untuk menentukan informan dan sampel. Informan dalam penelitian ini adalah pihak-pihak utama dalam kemitraan antara lain pihak Perum Perhutani (Mandor, Mantri, Asper, KPH Malang) dan Ketua LKDPH Wonolestari. Sedangkan sampel dalam penelitian ini adalah petani anggota program PKPH yang diambil sebanyak 30 anggota secara purposive.

\subsection{Teknik Pengumpulan Data}

Pengumpulan data dilakukan dengan wawancara mendalam (In Depth Interview) terhadap informan dan wawancara semi terstruktur kepada petani sampel. Teknik observasi dan dokumentasi juga dilakukan untuk melengkapi data.

\subsection{Teknik Analisis Data}

Analisis data yang dilakukan dalam penelitian ini ada dua jenis yang disesuaikan berdasarkan pendekatan penelitian. Pada pendekatan kualitatif menggunakan model interaktif Miles dan Huberman sedangkan untuk pendekatan kuantitatif menggunakan analisis usahatani. Analisis Model Interaktif Miles dan Humbermman, merupakan metode analisis data melalui tiga aktivitas analisis yang dilakukan secara interaktif dan berlangsung secara terus menerus sampai data jenuh atau tidak didapatkanya lagi data baru dalam penelitian. Ketiga aktivitas tersebut adalah reduksi data, penyajian data dan penarikan kesimpulan dan verifikasi. Sedangkan analisis pendapatan usahatani di lahan "Tetelan", menurut Soekartawi (1986) merupakan selisih antara penerimaan usahatani dengan total biaya usahatani. Adapun rumusnya sebagai berikut: a. Biaya usahatani didapatkan menggunakan persamaan berikut ini :

$\mathrm{TC}=\mathrm{TFC}+\mathrm{TVC}$

Keterangan :

$\mathrm{TC}=$ Total Biaya Usahatani Lahan "Tetelan" per Hektar (Rp)

TFC = Total Biaya Tetap per Hektar Lahan "Tetelan" (meliputi iuran wajib, penyusutan ajir) (Rp)

TVC = Total Biaya Variabel per Hektar Lahan "Tetelan" (meliputi biaya penggunaan benih, pupuk, pestisida, tenaga kerja, mulsa, dan polybag) (Rp)

b. Penerimaan usahatani didapatkan dengan menggunakan persamaan berikut ini :

$\mathrm{TR}=\mathrm{Q} \times \mathrm{P}$

Keterangan :

$\mathrm{TR}=$ Total Penerimaan Usahatani Lahan "Tetelan" per Hektar (Rp)

$\mathrm{P} \quad=$ Harga Satuan Produksi $(\mathrm{Rp} / \mathrm{Kg})$

$\mathrm{Q}=$ Jumlah Produksi per Hektar $(\mathrm{Kg})$

c. Pendapatan usahatani diperoleh dengan menggunakan persamaan berikut ini :

$\pi=\mathrm{TR}-\mathrm{TC}$

Keterangan :

$\pi \quad=$ Pendapatan Usahatani Lahan "Tetelan" per Hektar (Rp)

$\mathrm{TR}=$ Total Penerimaan Usahatani Lahan "Tetelan" per Hektar (Rp)

$\mathrm{TC}=$ Total Biaya Usahatani Lahan “Tetelan"per Hektar (Rp)

d. Pendapatan petani penyadap getah pinus dihitung melalui perkalian jumlah getah pinus (kg) yang mampu dipanen petani dikalikan dengan harga beli getah pinus per kg oleh Perum Perhutani yaitu sebesar Rp3.000,-.

\section{Hasil dan Pembahasan}

\subsection{Pola Kemitraan}

Kemitraan dalam program Pola Kemitraan Pengelolaan Hutan (PKPH) menurut pengelola Perum Perhutani di Kesatuan Pemangkuan Hutan (KPH) Malang secara sah dimulai sejak tahun 2004. Namun pelaksanaanya secara real sudah dimulai sejak tahun 2001 dimana ketika itu sudah dimulainya program Pengelolaan Hutan Bersama Masyarakat (PHBM) di seluruh Hutan Jawa dan Madura. Di Kabupaten Malang terjadi penyesuaian nama program PHBM menjadi PKPH serta terdapat penyesuaian penyebutan 
Lembaga Masyarakat Desa Hutan (LMDH) menjadi Lembaga Kemitraan Desa Pengelola Hutan (LKDPH).

Pihak utama dalam program PKPH adalah Perum Perhutani dengan masyarakat desa hutan. Pihak Perum Perhutani yang mengurus PKPH di Desa Kucur adalah satuan unit kerja di Resort Pemangkuan Hutan (RPH) Selorejo, Bagian Kesatuan Pemangkuan Hutan (BKPH) Kepanjen di Kesatuan Pemangkuan Hutan (KPH) Malang. Pada bagian satuan kerja ujung bawah yang sering berkumunikasi dan bertanggung jawab di lapangan dari pihak Perum Perhutani adalah Mandor dan Mantri Hutan yang berkantor di RPH Selorejo Kec. Dau. Sedangkan sebagai wakil dari masyarakat desa hutan di Desa Kucur adalah Lembaga Kemitraan Desa Pengelola Hutan (LKDPH) Wonolestari. Keberadaan lembaga ini merupakan salah satu syarat utama suatu desa bisa menjalankan sebuah program PKPH. Berdasarkan Pedoman PHBM yang dimaksud oleh LKDPH atau LMDH adalah lembaga masyarakat desa yang berkepentingan dalam kerjasama pengelolaan sumberdaya hutan bersama masyarakat, yang anggotanya berasal dari unsur lembaga desa dan atau unsur masyarakat yang ada di desa tersebut yang mempunyai kepedulian terhadap sumberdaya hutan. Masing-masing pihak saling membutuhkan satu sama lain ini sesuai dengan Menurut Puspawati (2004) konsep kemitraan idealnya kedua belah pihak yang bermitra harus saling membutuhkan dan saling menguntungkan.

Kedua pihak utama ini memiliki wewenang yang sama untuk saling menyampaikan ide-idenya hingga nanti diakhiri dengan perjanjian kemitraan. Isi perjanjian adalah semua yang menyangkut keseluruhan pelaksanaan program PKPH. Pelaksanaan program PKPH di Desa Kucur dilakukan dengan 2 kegiatan yaitu penyadapan getah pinus dan penggarapan lahan "Tetelan" (dibawah tegakan). Sistem bagi hasil penyadapan getah pinus adalah petani anggota kemitraan melakukan pemanenan getah pinus milik Perum Perhutani kemudian hasil panen akan dibagi hasil kepada petani tersebut dan bisa mengikuti kemitraan penggarap "Tetelan". Sedangkan sistem penggarapan lahan "Tetelan" adalah petani anggota kemitraan penggarap lahan "Tetelan" bukan penyadap yang melakukan penanaman tanaman pertanian di bawah pohon utama dengan kewajiban membantu menjaga kelestarian pohon utama serta ikut membantu kegiatan penyadapan getah pinus dengan membantu biaya operasional penyadap yang nominalnya disesuaikan kemampuan petani dan jumlah luasan lahan "Tetelan", namun umumnya biaya tersebut sekitar Rp 50.000,-/ 0,25 ha/ tahun.

Kelestarian hutan adalah fokus tujuan utama dari kemitraan program PKPH selain tujuan keuntungan ekonomi dan keadilan sosial. Inilah yang membedakan kemitaan dalam program PKPH dengan pola kemitraan yang lain. Umumnya kemitraan yang ada hanya memfokuskan pada keuntungan ekonomi saja. Namun apabila dibandingkan dengan kemitraan yang telah di atur di UU No.20 tahun 2008, kemitraan PKPH sistem penyadap getah pinus hampir memiliki kesamaan dengan pola kemitraan subkontrak yang ditandai dengan pembuatan kontrak perjanjian sebelum program dimulai dan adanya kesamaan ciri adanyaa dukungan yang diberikan oleh usaha besar yaitu kesempatan usaha kecil mengerjakan sebagian produksi maupun komponnenya; kesempatan usaha kecil memperoleh bahan baku yang diproduksi secara berkesinambungan; memberi bimbingan dan kemampuan teknis usaha; perolehan. Sedangkan pada sistem penggarap lahan "Tetelan" sulit bila disamakan dengan pola kemitraan yang telah ada karena tidak memiliki kesamaan ciri.

Selain LKDPH Wonolestari, PKPH di Desa Kucur terdapat kelembagaan non formal yang berkaitan dengan pengelolaan hutan berupa kelompok tani hutan. Ada tiga kelompok tani hutan yaitu Kelompok Tani Hutan Sumberbendo 1, Kelompok Tani Hutan Sumberbendo 2 dan Kelompok Tani Penyadap. Masing-masing lembaga ini memiliki fungsi untuk memudahkan komunikasi antar petani dan komunikasi dengan Perum Perhutani. Meski terdapat kelembagaan yang jelas namun kegiatan dari masing-masing lembaga tidak berjalan dengan baik. Tidak adanya kegiatan pertemuan yang jelas, kemudian pendataan anggota yang kurang maksimal menjadi indikator ketidak berjalanya lembaga tersebut. Lembaga LKDPH Wonolestari dan kelompok tani hutan terkesan hanya sebagai tempat pengumpulan sumbangan untuk kegiatan operasional penyadap. Hanya kelompok kemitraan hutan penyadap yang sering melakukan pertemuan serta memiliki cukup banyak kegiatan yang pasti. Kegiatan tersebut utamanya untuk peningkatan hasil perolehan sadapan yang didapat oleh petani penyadap.

Kemitraan penyadap lebih diutamakan oleh pihak Perum Perhutani karena dalam kemitraan tersebut berkaitan dengan bisnis Perum 
Perhutani sebagai perusahaan pengolah produk getah pinus. Petani yang ikut kegiatan sadapan berhak atas peralatan sadapan yang berupa banci (cangkul koakan), talang, sprayer, sarung tangan, sepatu boot atau lapang, seragam dan peralatan lainya secara gratis. Pada kemitraan penyadap getah, petani juga berhak untuk mendapat luasan lahan "Tetelan" yang lebih luas dengan bebas dari kewajiban membayar iuran.

\subsection{Aksesibilitas MDH}

Aksesibilas petani desa hutan merupakan peluang bagi petani masyarakat desa hutan untuk memperoleh kesempatan ikut mengelola hutan melalui kemitraan penggarap lahan "Tetelan" dan kemitraan penyadap getah pinus. Berdasarkan hasil penelitian diketahui jika petani memiliki aksesibilitas yang besar artinya tidak sulit untuk bisa ikut dalam kemitraan program PKPH. Program PKPH dijalankan dengan jiwa keseimbangan antara aspek sosial, ekonomi, ekologi. Salah satu nilai dalam aspek sosial yang dibangun di dalam program ini adalah keadilan. Nilai ini dibangun dengan tidak membatasi siapapun untuk ikut terlibat di dalam pengelolaan hutan. Sejak awal pembukaan pelaksanaan program PKPH dilakukan secara adil dan terbuka, seluruh masyarakat desa hutan tanpa terkecuali bisa ikut serta dalam program pengelolaan hutan ini.

Program PKPH dulu diawali dengan babat hutan atau pembukaan hutan yang gundul dan rusak, kemudian ditanami pepohonan kembali oleh petani masyarakat desa hutan peserta kemitraan. Pada kegiatan babat hutan inilah yang kemudian menentukan letak serta luasan lahan yang dimiliki karena pada saat itu semua peserta secara bebas berebut lokasi yang paling sesuai. Menurut Pengelolala Perum Perhutani tidak ada pembagian secara teratur karena hal tersebut akan menimbulkan kecemburuan sehingga pada saat itu bagi petani yang datang lebih awal serta memiliki kekuatan membabat lebih luas maka petani tersebut akan mendapat luasan yang diinginkanya.

Dengan petani ikut mengelola hutan dengan menanam pepohonan petani tersebut juga diizinkan menanam tanaman pertanian sebagai di sela-sela pohon tersebut. Setelah pohon itu besar dan rimbun yaitu sekitar umur 6 tahun, maka petani tidak bisa mengusahakan tanaman pertanian lagi. Sehingga untuk mendapatkan lahan "Tetelan" petani harus pindah ke tempat yang lebih memungkinkan dengan cara membuka lahan hutan kembali. Namun untuk pindah lokasi membutuhkan pengkajian yang cukup lama serta tidak bisa dipastikan waktunya, sehingga ketika lahan "Tetelan" awal sudah tidak memungkinkan ditanami karena kondisi pohon yang rimbun maka petani tersebut membuka di lahan lain yang sesuai untuk pertanian meski lahan tersebut tidak dibuka secara resmi oleh Perum Perhutani dan LKDPH. Kondisi inilah yang terjadi di program PKPH Desa Kucur yaitu tidak semua lahan yang dikelola kemitraan PKPH merupakan lahan resmi. Sebelumnya hal ini mendapat larangan oleh Perum Perhutani karena menyalahi aturan. Agar dapat memperoleh pendapatan petani masyarakat desa hutan didorong oleh Perum Perhutani untuk ikut ke kemitraan penyadap getah, namun tetap saja sebagian besar masyarakat kurang tertarik.

Dalam kegiatan usahatani lahan "Tetelan" di lahan yang tidak resmi ini dimaklumi oleh pihak Perum Perhutani dengan alasan kemanusiaan dan agar masyarakat desa hutan memiliki pandangan yang baik terhadap Perum Perhutani sehingga nantinya saling menjaga kepercayaan dan silahturahmi untuk bersamasama mengelola hutan. Petani penggarap lahan "Tetalan" tersebut akhirnya diizinkan menanam hanya dilokasi yang disadap oleh penyadap dan bertanggung jawab menjaga kelestarian pohon pinus tersebut. Petani penggarap "Tetelan" juga wajib izin terlebih dahulu kepada petani penyadap di lahan yang ditanaminya.

Mangacu pada pemilikan aset petani anggota PKPH mitra untuk menegetahui bagaimana sebaran pemilikan asetnya merata atau tidak sebagai bentuk indikator keadilan dalam aksesibilitas bisa dilihat dari Tabel 1. dan 2 berikut ini:

Tabel 1. Jumlah Petani Mitra Berdasarkan Pemilikan Luas Rumah di Desa Kucur, 2016

\begin{tabular}{cccc}
\hline No. & $\begin{array}{c}\text { Golongan Luas } \\
\text { Rumah }\left(\boldsymbol{m}^{\mathbf{2}}\right)\end{array}$ & $\begin{array}{c}\text { Jumlah } \\
(\text { Orang) }\end{array}$ & $\begin{array}{c}\text { Persentase } \\
(\boldsymbol{\%})\end{array}$ \\
\hline 1 & $<51$ & 8 & 27,0 \\
2 & $51-75$ & 13 & 43,0 \\
3 & $76-100$ & 6 & 20,0 \\
4 & $101-125$ & 0 & 0,0 \\
5 & $>125$ & 3 & 10,0 \\
\hline & Total & 30 & 100,0 \\
\hline
\end{tabular}

Menurut penyajian Tabel 1. dapat diketahui bahwa pemilikan rumah petani mitra cukup merata yaitu terdapat ukuran rumah yang kurang dari $51 \mathrm{~m}^{2}$, dengan persentase $27 \%$ kemudian pada ukuran $51-75 \mathrm{~m}^{2}$ sebesar $43 \%$. 
Pada kelompok selanjutnya ukuran rumah 76$100 \mathrm{~m}^{2}$ sebesar 20\%, pada kelompok 101-125 $m^{2}$ tidak ada dan kelompok terakhir, yang memiliki rumah berukuran lebih dari $125 \mathrm{~m}^{2}$ sebesar $10 \%$.

Berdasarkan kondisi bangunan rumah, dari 30 petani mitra yang diambil 6 petani memiliki kondisi bangunan yang semi permanen. Kondisi semi permanen tersebut dilihat dari kondisi tembok yang belum terbuat dari batu bata atau masih menggunakan anyaman bambu. Selain itu kondisi alas rumah masih belum dipondasi atau masih tanah saja. Kemudian 24 diantaranya sudah memiliki kondisi yang baik:

Tabel 2. Jumlah Petani Mitra Berdasarkan Pemilikan Luas Lahan Milik di Desa Kucur, 2016

\begin{tabular}{cccc}
\hline No. & $\begin{array}{c}\text { Luas Lahan } \\
\text { Milik (ha) }\end{array}$ & $\begin{array}{c}\text { Jumlah } \\
\text { (Orang) }\end{array}$ & $\begin{array}{c}\text { Persentase } \\
(\boldsymbol{\%})\end{array}$ \\
\hline 1. & 0 & 3 & 10 \\
2. & $0,1-0,25$ & 16 & 53 \\
3. & $0,26-0,5$ & 7 & 23 \\
4. & $0,51-0,75$ & 4 & 14 \\
5. & $>0,75$ & 0 & 0 \\
\hline & Total & 30 & 100,0 \\
\hline
\end{tabular}

Berdasarkan Tabel 2. dapat diketahui bahwa sebagian besar petani mitra memiliki luas lahan milik pribadi sebesar $0,1-0,25$ ha yaitu $53 \%$. Golongan selanjutnya terdapat $23 \%$ yang memiliki lahan milik sebesar 0,26-0,5 ha. Bahkan ada juga yang tidak memiliki lahan milik sama sekali, ini terjadi di 3 responden. Petani mitra lainya yang memiliki lahan milik antara 0,51 0,75 ha ada $23 \%$ dan yang memiliki lahan diatas 0,75 ha tidak ada.

Selain pemilikan rumah dan lahan milik sendiri untuk aset lain seperti ternak tidak dimiliki oleh semua petani mitra. Aset jenis ternak ini lebih digunakan sebagai sebuah tabungan atau bentuk infestasi oleh responden untuk berjaga-jaga diwaktu paceklik atau antisipasi kebutuhan mendesak diwaktu mendatang. Aset penting lain seprti motor hampir dimiliki oleh seluruh reesponden yang ada, hanya 2 responden yang tidak memiliki motor. Umumnya motor ini diguakan sebagai alat transportasi responden untuk ke lahan dan bepergian sehari-hari.

Bisa disimpulkan bahwa berdasarkan pemilikan aset yang ada, responden dalam penelitian ini memiliki karakter yang cukup sama. Berdasarkan pemilikan rumah dan lahan milik yang dapat menjadi sebuah ukuran kekayaan seorang petani, menunjukkan kekayaan petani anggota kemitraan cukup kecil yaitu dengan pemilikan rumah yang sederhana dan luas lahan yang dimiliki semua dibawah 0,75 ha. Meskipun dalam aksesibilitas tidak ada pembatasan terhadap siapapun, petani kaya atau petani miskin tetap saja sebagian besar anggota petani yang ikut kemitraan PKPH adalah petani yang termasuk kategori miskin yang memiliki lahan milik kurang dari 1 ha.

Peneliti juga memperoleh data dari beberapa petani non kemitraan baik penyadap maupun penggaraap lahan "Tetelan". Informasi tersebut menegaskan jika semua anggota masyarakat boleh ikut dalam kemitraan PKPH atau terlibat dalam pengelolaan hutan. Alasan mengapa mereka tidak ikut serta adalah sudah memiliki lahan yang cukup sehingga tidak memiliki waktu dan tenaga untuk bisa amengelola lahan di hutan. Selain itu ada juga yang berhenti mengerjakan lahan hutan karena usia sudah tua, dan tidak sanggup untuk bekerja di lahan yang jauh. Karena umumnya jarak antara pemukiman petani dengan lokasi hutan sekitar $1,5 \mathrm{~km}$ dengan jalan yang cukup curam.

\subsection{Kesesuaian Implementasi Program PHBM Berdasarkan Kelestarian Hutan}

\section{a. Sistem Penggarap Lahan "Tetelan" \\ Setidaknya dalam kemitraan penggarap} "Tetelan" terdapat 8 indikator yang digunakan oleh peneliti untuk mengukur bagaimana tingkat kesesuaian program PKPH dalam mencapai tujuan kelestarian hutan. Adapun dibawah ini Tabel 3. akan menunjukkan hasil pengolahan data tentang kesesuaian implementasi program PKPH berdasarkan kelestarian hutan di Desa Kucur:

1) Indikator Jumlah Pohon Pinus yang Hidup

Dari Tabel 3. diketahui berdasarkan dari indikator jumlah pohon yang hidup dalam kemitraan PKPH adalah kategori tinggi dimana memiliki persentase terhadap skor maksimal adalah $90 \%$. Skor tinggi ini tidak bisa sempurna $100 \%$ bukan karena ada pencurian atau penjarahan oleh masyarakat desa hutan melainkan beberapa pohon mati karena kebakaran dan terkena bencana angin. Berdasarkan pencocokan keterangan dari pihak Perum Perhutani dengan masyarakat memang saat ini sudah tidak ada praktek pencurian hutan mengingat sanksinya cukup berat. 
Tabel 3. Indikator Kesesuaian Pelaksanaan Program PKPH di Lahan "Tetelan" di Desa Kucur Tahun $2015 / 2016$

\begin{tabular}{llcccc}
\hline No. & \multicolumn{1}{c}{ Indikator } & $\begin{array}{c}\text { Perolehan } \\
\text { Total Skor }\end{array}$ & Rata-Rata Skor & $\begin{array}{c}\text { Persentase } \\
(\boldsymbol{\%})\end{array}$ & Ketegori \\
\hline 1. & Jumlah Pohon & 82 & 2,7 & 90 & Tinggi \\
2. & Kondisi Kanopi & 79 & 2,6 & 87 & Tinggi \\
3. & Jarak Tanam & 87 & 2,9 & 97 & Tinggi \\
4. & Tanaman Petani & 38 & 1,3 & 43 & Rendah \\
5. & Intesitas Penyiangan & 47 & 1,6 & 53 & Sedang \\
6. & Intensitas Pemupukan & 41 & 1,4 & 47 & Rendah \\
7. & Pengolahan Lahan & 42 & 1,4 & 47 & Rendah \\
8. & Kesediaan Tanam Kopi & 60 & 2,0 & 67 & Sedang \\
\hline \multicolumn{2}{r}{ Total } & 476 & 15,9 & - & Sedang \\
\hline
\end{tabular}

2) Indikator Kondisi Kanopi Pohon Pinus karena di Rempes/Tidak

Dari penyajian Tabel 3. diketahui berdasarkan kondisi kanopi pohon pinus karena kegiatan perempesan masih menunjukkan bahwa dalam kondisi kategori tinggi yakni memiliki persentase terhadap skor maksimal sebesar $87 \%$. Dengan demikian meskipun terdapat kegiatan perempesan pohon pinus, kondisi pohon masih tergolong baik karena kondisi kanopi pinus lebih dari $60 \%$.

3) Indikator Jarak Tanam Tanaman Pertanian dengan Pohon Pinus

Jarak tanam yang sudah diatur oleh Perum Perhutani untuk dipakai dalam penanaman tanaman pertanian dari pohon pinus adalah minimal $1 \mathrm{~m}$. Meski demikian tidak semua petani mitra mentaatinya. Ini disebabkan oleh keinginan petani untuk mendapatkan hasil yang lebih besar dengan pengoptimalkan lahan hingga menyampingkan risiko rusaknya akar karena terkena cangkul petani yang menanam tanamaan terlalu dekat pohon pinus. Berdasarkan tabel 3. menunjukkan bahwa berdasarkan indikator pemakaian jarak tanam antara tanaman pertanian dengan pohon pinus dalam katogori tinggi atau sesuai dengan persentase yang mendekati sempurna yaitu 97\%. Dengan hasil diatas menunjukkan bahwa meskipun ada beberapa petani melanggar namun persentasenya kecil.

4) Indikator Jenis Tanaman yang Saat ini Dibudidayakan

Berdasarkan Tabel 3. maka dapat diketahui bahwa hasil dari pengukuran indikator keempat yaitu dari jenis tanaman yang dibudidayakan di lahan "Tetelan" termasuk dalam kategori rendah atau kurang sesuai. Dari skor yang dapat diperoleh sebesaar 3, rata-rata skor yang dapat dicapai oleh petani mitra hanya 1,3 atau memiliki persentase terhadap skor maksimal sebesar $43 \%$ saja. Masyarakat desa hutan yang ada di Desa Kucur memiliki pengalaman menanam komoditas hortikultur secara terus menerus. Hal yang kurang sesuai ini beberapa kali dicoba diubah oleh Perum Perhutani dengan mengajak menanam komoditas yang lebih ramah lingkungan yaitu jenis tanaman obat-obatan atau empon-empon dan kopi.

5) Indikator Intensitas Penyiangan di Lahan "Tetelan"

Menurut mantri hutan sewajarnya kegiatan penyiangan yang pas adalah sekali dalam sebulan dengan tanpa pemberian obat kimia herbisida. Diketahui bahwa berdasarkan indikator kelima kesesuaian kelestarian masuk dalam kategori sedang dengan nilai persentase terhadap skor maksimal sebesar 53\%. Nilai tersebut diketahui melalui rata-rata skor yang dicapai dlapang hanya 1,6. Dengan demikian praktek penyiangan yang dilakukan oleh petani anggota kemitraan "Tetelan" perlu dikurangi. Umumnya intensitas penyiangan yang dilakukan oleh petani mitra adalah $2 x$ dalam sebulan.

6) Indikator Intensitas Pemupukan

Mengacu pada Tabel 3. dapat diketahui bahwa berdasarkan intensitas pemberian pupuk menunjukkan hasil kesesuaian kelestarian hutan kurang sesuai karena berada dalam kategori rendah. Dengan nilai persentase terhadap skor maksimal hanya $47 \%$ yang memiliki rata-rata skor dilapang sebesar 1,4. Dalam praktek lapang biasanya pemupukan yang dilakukan oleh petani adalah 2 kali dalam sebulan bahkan pada komoditas cabai keriting bisa satu bulan 4x.

Kebiasaan kurang baik masyarakat Desa Kucur yang mengerjakan lahan "Tetelan" adalah memberi pupuk organik berupa kotoran ayam disetiap awal musim tanam. Setelah pemberian 
pupuk organik tersebut setelah terdapat tanaman pun juga masih diberi pupuk kimia. Pemberian pupuk ini juga menjadi koreksi dari Perum Perhutani, karena dengan pemberian pupuk tersebut membuat daun pohon pinus menguning.

7) Indikator Intensitas Pengolahan Lahan

Menurut mantri hutan dalam sekali musim pengolahan yang memperhatiakan kelestarian yang hanya dilakukan 1 pengolahan saja. Berdasarkan Tabel 3. dapat diketahui berdasarkan indikator intensitas pengolahan lahan, program PKPH belum sesuai karena hasil yang diperoleh berada dalam kategori rendah. Dengan persentase terhadap skor maksimal hanya $47 \%$ yang mana nilai rata-rata skor yang dicapai sebesar 1,4 saja.

Pengolahan yang dilakukan dalam 1 tahun oleh masyarakat Desa Kucur umumnya sebanyak $3 x$. Pengolahan pertama biasanya diawal tanam ditanami oleh tanaman bunga kol, dan bawang merah. Setelah tanaman pertama mulai tumbuh kemudian lahan tersebut ditanami oleh tanaman cabai, terong, kacang dan jenis tanaman lain. Setelah tanaman pertama panen kemudian sisa panen dibersihkan dengan tujuan tidak mengganggu tanaman yang lainya yang masih hidup. Lalu setelah tanaman cabai, terong dan tanaman lainya mulai panen, petani akan menanami tanaman jagung dibawahnya.

8) Kesediaan Mengganti Komoditas Horti menjadi Kopi

Tanaman kopi menurut mantri hutan dianggap lebih sesuai ditanam di lahan "Tetelan" karena tanaman kopi bisa mengurangi intensitas pengolahan tanah, pemupukan dan intesitas penyiangan. Dengan melihat Tabel 3. dapat diketahui indikator kesedian berganti komoditas kopi menunjukkan hasil yang termasuk dalam kategori sedang. Dengan nilai presentase terhadap skor maksimal sebesar $63 \%$ atau memiliki rata-rata skor yang dicapai dilapang sebesar 1,9. Saat ini yang telah berganti komoditas kopi cukup banyak, dan sepertinya akan terus bertambah karena salah satu anggota telah berhasil menanam kopi dengan hasil yang cukup memuaskan.

Secara keseluruhan untuk menilai pelaksanaan program PKPH secara penuh berdasrkan seluruh indikator secara bersamasama hasilnya adalah tergolong sedang. Dimana dari hasil skor yang diperoleh dari semua indikator memiliki jumlah 472 dengan keseluruhan responden adalah 30. Dengan demikian rata-rata skor tiap responden adalah sebesar 15.86 berada pada daerah sedang yang dimulai oleh nilai 13,34 hingga 18,66.

Meskipun dari hasil skoring menunjukkan kesesuaian implementasi berdasarkan kelestarian hutan berada di kategori sedang namun secara keseluruhan semua petani memiliki persepsi yang baik terhadap seluruh kebijakan Perum Perhutani. Semua petani mitra menyadari bahwa kelestarian hutan sangat penting bagi kelangsungan hidup mereka dan mereka merasa perlu untuk terus menjaga kelestarian hutan. Selain itu semua responden juga mengakui beberapa praktikpraktik kurang baik yang menjadi penghambat kelestarian hutan masih dilakukan oleh petani responden itu sendiri. Alasan yang digunakan oleh hampir semua responden untuk tetap menganggap wajar praktik kurang baik tersebut adalah tuntutan kondisi serta melihat praktik yang sama oleh teman/tetangganya.

\section{b. Kemitraan Penyadap Getah Pinus}

Pelaksanaan kemitraan penyadap getah pinus termasuk dalam kategori yang baik. Kegiatan dalam penyadapan tidak terlalu mengandung resiko kerusakan hutan selain itu setiap penyadap juga telah memahami bagaimana menyadap yang baik agar pohon pinus bisa tetap lestari. Pelaksanaan penyadapan oleh petani penyadap sudah sesuai aturan dasar utamanya dalam tetap menjaga kesehatan pohon pinus meskipun ada beberapa cara tidak mengikuti ketentuan dari mantri hutan. Masing-masing alasan tersebut tidak terlalu berpengaruh pada keletarian hutan utamaanyaa pohon pinus karena masing-masing pihak telah menganggap kelestariaan pohon begitu penting.

\subsection{Analisis Pendapatan Petani dalam Kemitraan PKPH}

a. Analisis Pendapatan Usahatani dalam Kemitraan Penggarap Lahan "Tetelan"

Pada kemitraan penggarap lahan "Tetelan" umumnya petani anggota menanam tanaman hortikultura yang memakai sistem tumpang sari. Kombinasi dalam memilih tanaman yang dibudidayakan setiap petani sangat beragam dan sulit dikategorikan. Meskipun kombinasinya sulit dikelompokan namun dari 30 petani responden yang peniliti ambil terdapat 11 tanaman yang dibudidayakan di lahan "Tetelan" selama satu musim tanam. Adapun komoditas yang dibudidayakan oleh petani adalah: Jagung, Cabai Keriting, Jahe, Kopi, Buncis, Kacang Tanah, 
Terong, Bunga Kol, Bawang Merah, dan Cabai Besar.

Umumnya petani dalam satu kali musim tanam di lahan "Tetelan" dimulai pada Bulan Desember hingga Bulan Agustus (8 bulan) dan memiliki kombinasi dua hingga tujuh tanaman. Dalam aplikasinya ada yang ditanam secara langsung juga ada yang diatur secara petak-petak kecil monokultur. Setiap petani memiliki alasan pribadi dalam memilih kombinasi tersebut namun sebagian besar alasanya adalah kebiasaan tahunan dan ikut-ikut tetangga atau petani lain. Setiap tahun umumnya petani memilih tanaman yang sama untuk dibudidayakan. Selain itu beberapa petani mitra juga menyampaikan bahwa jika tanaman yang ditanam oleh semua petani sama maka menunjukkan kerukunan warga desa.

1) Biaya Usahatani lahan "Tetelan"

Biaya usahatani lahan "Tetelan" terdiri dari biaya tetap dan biaya variabel. Adapun dibawah ini, akan ditunjukan oleh Tabel 5. tentang rata-rata total biaya usahati di lahan "Tetelan":

Tabel 5. Biaya Usahatani di lahan "Tetelan" Per Hektar di Desa Kucur Tahun 2015/ 2016

\begin{tabular}{lrr}
\hline Uraian & $\begin{array}{c}\text { Rata-Rata } \\
\text { Biaya (Rp) }\end{array}$ & $\begin{array}{c}\text { Persentase } \\
(\mathbf{\%})\end{array}$ \\
\hline Biaya Tetap : & & \\
- $\quad$ Penyusutan & 1.713 .333 & 14,0 \\
$\quad$ Ajir & & \\
- $\quad$ Pajak Lahan & 103.056 & 0,8 \\
Sub Total & 1.816 .389 & 14,8 \\
- $\quad$ Benih & 2.477 .511 & 20,5 \\
- Pupuk & 3.760 .917 & 30,9 \\
- Pestisida & 1.517 .600 & 12,6 \\
- $\quad$ Tenaga Kerja & 2.465 .917 & 20,3 \\
- Polybag & 100.423 & 0,9 \\
Sub Total & 10.322 .368 & 85,2 \\
\hline Total & 12.208 .757 & 100 \\
\hline
\end{tabular}

Pada Tabel 5. menunjukkan bahwa biaya yang paling besar untuk usahatani di lahan "Tetelan" adalah biaya pupuk yang mencapai $30,9 \%$ dari jumlah total biaya usahatani. Biaya yang juga besar dikeluarkan oleh petani penggarap lahan "Tetelan" adalah biaya untuk beih dan tenaga kerja. Biaya benih mencapai $20,5 \%$ dan biaya tenaga kerja mencapai $20,3 \%$. Pupuk yang digunakan oleh petani lahan "Tetelan" adalah pupuk anorganik dan organik. Rata-rata petani mitra mengeluarkan biaya usahatani sebanyak Rp12.208.757,-- untuk satu hektar lahan "Tetelan"yang diusahakan pada musim tanam 2015/ 2016.

2) Penerimaan usahatani lahan "Tetelan"

Berikut hasil penerimaan tersebut akan ditunjukan oleh Tabel 20. tentang rata-rata penerimaan setiap komoditas/ha setiap petani mitra:

Tabel 6. Penerimaan Usahatani Setiap Komoditas per Ha per Petani Mitra Penggarap Lahan "Tetelan" di Desa Kucur, 2015/2016

\begin{tabular}{clc}
\hline No. & Komoditas & Jumlah/ha $(\mathbf{R p})$ \\
\hline 1. & Cabai Besar & 2.017 .586 \\
2. & Cabai Keriting & 9.047 .133 \\
3. & Cabai Rawit & 4.122 .633 \\
4. & Jagung & 1.730 .222 \\
5. & Terong & 926.075 \\
6. & Jahe & 5.698 .700 \\
7. & Bunga Kol & 78.333 \\
8. & Kacang Tanah & 1.073 .100 \\
9. & Bawang Merah & 858.966 \\
10. & Buncis & 626.600 \\
11. & Kopi & 286.400 \\
\hline & Total & 26.369 .864 \\
\hline
\end{tabular}

Besar kecilnya penerimaan yang diperoleh masing-masing petani mitra tergantung dari kombinasi yang telah mereka pilih. Berdasarkan tabel 20. dapat diketahui bahwa rata-rata setiap petani memperoleh penerimaan dari kombinasi komoditas yang mereka usahakan dalam 1 musim tanam adalah sebesar Rp26.396.864,00. Dari hasil analisis data yang dapat dilihat di bagian lampiran, ditunjukan bahwa dari 30 petani mitra memiliki penerimaan yang cukup rata. Terdapat nilai penerimaan minimal sebesar $\mathrm{Rp} 0$,- yang dialami oleh 1 petani mitra karena komoditas kopi yang petani tersebut budidayakan belum panen. Namun 29 petani mitra yang lain memiliki nilai penerimaan antara Rp12.686.000,00 hingga Rp40.814.000,00.

Khusus pada komoditas kopi yang merupakan tanaman baru bagi petani mitra, ternyata dianggap cukup memiliki hasil yang cukup tinggi oleh petani mitra. Dari seluruh petani penggarap lahan "Tetelan" yang sudah menanam komoditas kopi hanya ada satu petani saja yang sudah panen dan merupakan panen pertama kali. Dari hasil produksi panen dan harga pertama tersebut, dianggap menguntungkan oleh petani mitra yang lain. Setelah melihat hasil produksi kopi dan harganya cukup tinggi banyak anggota lain yang sebelumnya tidak berniat 
menanam kopi akhirnya ikut tertarik menanam kopi.

3) Pendapatan Usahatani di Lahan "Tetelan"

Adapun di bawah ini pada Tabel 7. akan ditunjukan bagaimana rata-rata pendapatan dari 11 komoditas yang di masing-masing telah dikombinasikan oleh petani mitra yang ada di lahan "Tetelan":

Tabel 7. Pendapatan Usahatani per Ha per Petani mitra di Lahan "Tetelan" di Desa Kucur, 2016

\begin{tabular}{clc}
\hline No. & \multicolumn{1}{c}{ Uraian } & $\begin{array}{c}\text { Jumlah/ha } \\
(\mathbf{R p})\end{array}$ \\
\hline 1. & Total Biaya & 12.208 .757 \\
2. & Biaya Tetap & 1.816 .389 \\
3. & Biaya Variabel & 10.322 .368 \\
4. & Penerimaan & 26.369 .864 \\
5. & Pendapatan & 14.161 .137 \\
\hline
\end{tabular}

Berdasarkan Tabel 7. dapat diketahui bahwa total pendapatan petani mitra per hektar sebesar Rp14.161.137,00. Hasil pendapatan sebesar ini didapat oleh petani mitra dalam sekali musin tanam selama 8 bulan yaitu dimulai pada Bulan Desember hingga Bulan Juli. Maka jika dihitung rata-rata pendapatan petani mitra per ha dalam satu bulan adalah adalah sebesar Rp1.770.158,00. Dengan rata-rata petani hutan memiliki lahan $1 / 4$ ha, maka dapat diketahui juga setiap petani mitra penggarap lahan tetalan tersebut memperoleh pendapatan sebesar Rp442.539,00. Pendapatan tersebut oleh petani mitra dianggap kecil, karena pada musim-musim sebelumnya mereka mampu memperoleh pendapatan yang lebih besar.

b. Analisis Pendapatan Penyadap Getah Pinus

Hasil sadapan rata-rata tiap petani penyadap $660 \mathrm{~kg}$ ini didapatkan penyadap selama 8 bulan atau 16 kali periode penimbangan. Jika rata-rata tersebut dibagi menjadi 16 kali periode dapat diketahui jika setiap periode penyadap hanya mampu menghasilkan 41,25 kg dengan nilai $\mathrm{Rp} 123.750,00$ jika diungkan setiap 15 hari sekali atau pendapatan dalam sebulan sebesar Rp247.500,00. Pendapatan per bulan dari kemitraan ini lebih kecil jika dibandingkan dengan pendapatan kemitraan penggarap "Tetelan" yang mencapai Rp442.540,00 tiap bulan. Pendapatan dari kedua kemitraan tersebut cukup jauh. Dimana nilai pendapatan penggarap lahan "Tetelan" hampir 2x lipat dari nilai pendapatan penyadap lahan "Tetelan".
Namun peneliti menemukan fakta bahwa sebenarnya apabila petani penyadap getah pinus bisa bekerja rutin bisa mendapat pendapatan yang besar. Seperti yang dilakukan oleh penyadap di Desa Selorejo yang mampu memperoleh pendapatan sebesar Rp3.000.000,- setiap bulan. Fakta tersebut sebenarnya juga sudah diketahui oleh penyadap Desa Kucur tetapi mereka tetap tidak tertarik dengan kegiatan penyadapan. Alasan utama yang mendasari hal tersebut adalah kepuasan hati dari masing-masing petani mitra.

Semua petani mitra merasa lebih puas jika memiliki tanaman atau bila bercocok tanam meski mereka juga memahami bahwa dalam kegiatan usahatani di lahan "Tetelan" lebih memiliki risiko kerugian yang lebih besar dibanding dengan mengikuti kegiatan penyadapan. Petani mitra menganggap bahwa pekerjaan utama mereka adalah petani yang becocok tanam, sedangkan kegiatan penyadapan adalah kegiatan tambahan untuk menambah pemasukan terutama pada saat lahan pertanian mereka tidak memungkinkan untuk bercocok tanam.

\section{Kesimpulan}

Kemitraan dalam program Pola Kemitraan Pengelola Hutan (PKPH) dijalankan oleh Perum Perhutani dan masyarakat desa hutan Desa Kucur dengan berlandaskan kesepakatan perjanjian yang disetujui oleh kedua belah pihak. Isi perjanjian tersebut adalah wujud dari pengelolaan hutan yang berprinsip pada kelestarian hutan dan peningkatan kesejahteraan masyarakat desa hutan. Dalam pelaksanaan di lapang, berdasarkan aksesibilitas masyarakat desa hutan untuk ikut dalam pengelolaan hutan dilaksanakan secara adil dan terbuka.

Tingkat kesesuaian implementasi program PKPH di Desa Kucur berdasarkan kelestarian hutan pada kemitraan penggarap lahan "Tetelan" adalah berada pada kategori sedang yaitu dengan skor 15,86. Dengan masing-masing nilai indikator kesesuaian sebagai berikut: indikator jumlah pinus yang hidup sebesar kategori tinggi, indikator kondisi kanopi yang disebabkan perempesan kategori tinggi, indikator jenis tanman pertanian kategori rendah, indikator jarak tanam kategori tinggi, indikator penyiangan kategori sedang, indikator pengolahan lahan lahan kategori rendah, indikator pemupukan kategori rendah dan indikator menanam kopi katagori sedang. Sedangkan pada kemitraan penyadap pelaksanaanya cukup baik, semua anggota penyadap telah memahami dan 
menerapkan bagaimana cara menyadap yang baik agar pohon pinus tetap lestari.

Terdapat perbedaan hasil pendapatan dari kedua jenis kemitraan yang diikuti oleh petani dalam program PKPH di Desa Kucur. Hasil analisis pendapatan usahatani dalam kemitraan lahan "Tetelan" per petani per ha adalah sebesar Rp14.161.137,00 selama 8 bulan atau dengan pendapatan per bulan per $1 / 4$ ha sebesar Rp442.540,00. Sedangkan pada analisis pendapatan kemitraan penyadap getah pinus selama 8 bulan adalah sebesar Rp1.980.000,00 atau setiap bulan per penyadap mendapat pendapatan sebesar Rp245.500,00. Perbedaan pendapatan antara kedua kemitraan ini cukup jauh yaitu memiliki jarak $2 x$ lipat. Hal ini disebabkan oleh petani penyadap memang lebih fokus pada kegiatan kemitraan usahatani di lahan "Tetelan".

\section{Daftar Pustaka}

Achirrudin, D. R. 2011. Implementasi Kebijakan Pengelolaan Hutan Bersama Masyarakat (PHBM) Perum Perhutani Bagian Kestauan Pemangkuan Hutan Temanggung dalam Rangka Pelestarian Hutan Lindung di Gunung Sumbing-Sindoro [Tesis]. Fakultas Hukum. Universitas Sebelas Maret.

Aji, G. B., Suryanto, J., Yulianti, R., Wirati, A., Abdurrahim, A. Y., Miranda, T. I. 2011. Strategi Penguraangan Kemiskinan di Desa-Desa Sekitar Hutan. Pusat Penelitian Kependudukan Lembaga Ilmu Pengetahuan Indonesia. Jakarta.

Ansori, M., Soetarto, E.,Darusman, D., Sundawati, L.,2009. Pengelolaan Hutan Kemitraan untuk Menyejahterakan Rakyat(Kasus PHBM di Perhutani BKPH Parung Panjang, KPH Bogor). Fakultas Ekologi Pertanian dan Fakultas Kehutanan. Institut Pertanian Bogor. Bogor.

Kusdamayanti. 2008. Peran Masyarakat dalam Penyusunan Kebijakan Pola Kemitraan Pengelolaan Hutan di Kabupaten Malang. Jurnal Peenelitian Sosisal Ekonomi Kehutanan Vol. 5 No. 2 Juni 2008, Hal. 111-124.

Miles, B. Mathew dan A Michael Huberman. 1992. Analisis Data Kualitatif. Universitas Indonesia Press: Jakarta.
Perum Perhutani, 2009. Pedoman Pengelolaan Hutan Bersama Masyarakat (PHBM); Jakarta.

Puspawati. 2004. Analisis Kemitraan antara PT. Petani (Persero) dengan Petani Penangkar Benih Padi di Kabupaten Karawang. Tesis Institut Pertanian Bogor. Bogor.

Soekartawi. 1986. Ilmu Usahatani dan Penelitian untuk Pengembangan Petani Kecil. UIPress: Jakarta.

Undang-Undang No. 5 Tahun 1967 Ketentuan Pokok Kehutanan.

Undang-Undang No. 20 Tahun 2008. Tentang Usaha Mikro, Kecil dan Menengah. 